\title{
Multi-hierarchical Framework - Fuzzy Entropy Weight Approach for Auditing Technology in PT
}

\author{
Achmad Danu Firdaus Xan Udisubakti Ciptomulyono \\ Department of Industrial Engineering, Faculty of Industrial Technology, Institut Teknologi Sepuluh \\ Nopember (ITS) \\ e-mail: udisubakti@ie.its.ac.id
}

\begin{abstract}
PT $\mathrm{X}$ is an Indonesia leading company in ship repair field. With the growth of shipyard industries in Indonesia, company is expected to compete within tight competition. Problems arise when the reparation processes can't be finished on schedule. Respect to high vessel repairing demands, it can be a serious problem for company as they have many of ships waiting to be repaired. Management of technology might be the first step to solve the problem. Repair process within company is supported due to good management of technology policies. That's why technology assessment is necessary in this company. This research is proposed to be used as recommendation to PT $X$ on how to measure and assess the technological capabilities of company. Technology Audit Model (TAM) is used as basic technology assessment model. While multi-hierarchical framework - Fuzzy Entropy Weight Approach (FEWA) are tools used to process the multi-criteria of assessment model. Based on the assessment, it can be known the weight and rank of all criteria, by which are be utilized as input for SWOT analysis. Based on this process, the the improvement strategies could be generated. The proposed strategies are knowledge sharing program, environmental impact evaluation, and project network.
\end{abstract}

Keywords-FEWA, MCDM, Multi-hierarchical Framework, SWOT, Technology Assessment, Technology Audit Model.

\section{INTRODUCTION}

I NDONESIA is the world's largest archipelago. With the wealth and large coverage of sea, the investment and optimal exploitation of maritime sector in Indonesia can bring full advantages and support the country's economic growth. According to Peraturan Presiden (Perpres) Nomor 16/2017 about Indonesian maritime policies, Indonesia has aim to set the country as a maritime power in the world. One of five pillars of developing Indonesian maritime power is infrastructure and maritime connectivity development [1]. Indonesian National Ship-owners Association (INSA) stated that national shipyard industries have significant correlation toward maritime connectivity development in Indonesia, since shipyard industries give full support to sea transportation activity, with the power of vessel building and repair.

Shipyard industry basically runs in ship building and ship repair business. Most shipyards are concentrated along the coasts, like Surabaya, Jakarta, and Batam in Indonesia. In fact, shipyard market has high potential in Indonesia since there are many ship demands with various types from local and global markets over years. The need for the ship will continue to increase, so does the need of maintenance. Moreover
Indonesian government is intensively boosting the maritime sector. So the growth of shipgard industries in Indonesia is expected to increase thishnfikiqtgredented sector become more competitive.Category No $\quad$ Criteria

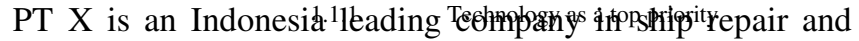

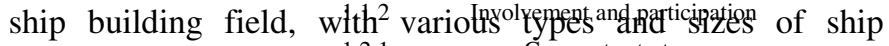
ordered by clients around the world. Gorperate strategy company experts in ship repair sector, with $4_{1.2 .}^{2}$. floating dock Gothe shipyard. PT X focuses on ship repair actiyity rather than ship construction. In January until September.32017, there areanitordifferent vessels repained iñ inechnglogicalmpany, compared toulthes ship built. This happens because according to the compiangrgtheatrepair activity bring more economic profit than buildfipgenguxtiptity.

Problems arise when ${ }^{1}$ the reparation to be completed on schedtule. In fact, socruiting oolieiet the reparation orders can't be finished.5.2. on time. Witraining hy vessel repair

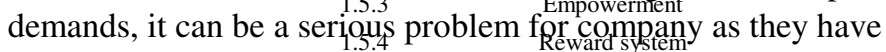

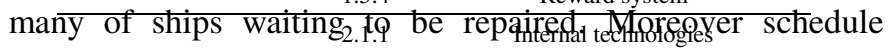
accuracy are included in very impontantattrihattegefor customer satisfaction [2]. Since 2.time of comappletdionlogiss one of the important attribute to afitact customershneognpenty must find a

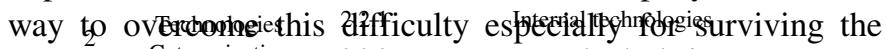

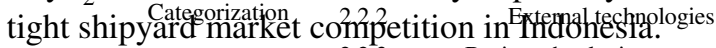

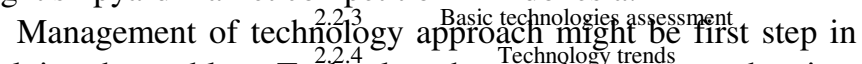

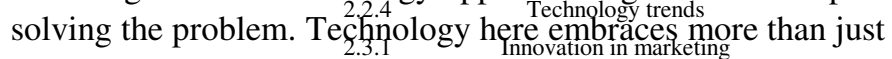
machines since there are.several technoldogicale entities besides

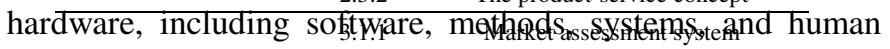

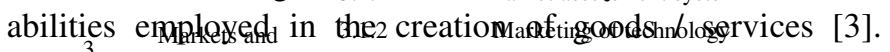
Managemefipmofiterehnology neededCaspaittook the systems that enable 3 ereation, acquissitliosfiking exploitation

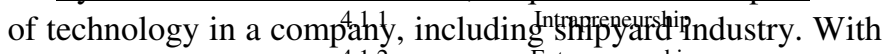

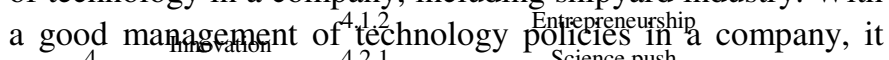

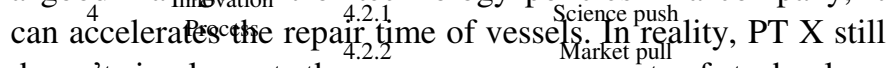
doesn't implement the .2.2 proper management of technology policies yet. They don'5. know the cighteranctition to the exploit and manage their various technologiespariol justatyatite meet their demand and atundate business. Moreowersthietyestidlydan't identify and measurenctipeir techablogical positioneme the thuth is

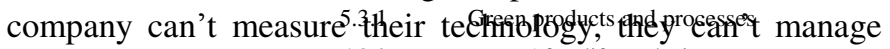
their technology propering. So, tectith-ilifo anglysisssessment is necessary in this company. Assessment provides a gap determination between ${ }_{\text {Accuisition and }}^{6.2}$ the existing antal investment and the desired

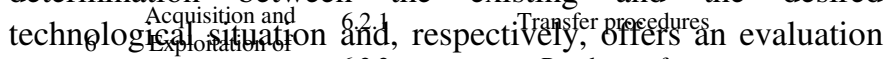

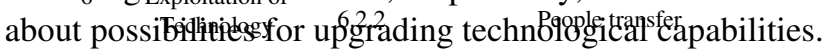

$$
\text { 6.3.1 Exploitation for profit }
$$$$
\text { 6.4.1 Protection }
$$ 
Technology Audit Model (TAM) can be used as technology assessment model. It is one of internal technology audit methods used in management of technology to identify and assess the strength and company's technology position in business competition to take advantage and seek for opportunities from company's capabilities [4]. Basically TAM focuses more in functionality of company in thoroughly not only in the technological hardware scope. Therefore it is suitable with the selected object since in this business, the critical things in doing reparation processes are not only related to technological scope but the interaction between the functional organization to support the activity. However, adjustment of this model is conducted to have better assessment model which is suitable with PT $\mathrm{X}$ business process, especially in ship repair process.

To support the implementation of many assessment criteria like that, can be used a multi-criteria decision making approach as the weighting or assessment tools. The assessment will be conducted internally with the help of internal experts from company. Fuzzy Entropy Weight Approach (FEWA) as MCDM tool is suitable for this kind of problem. This method is selected over other methods because of its simplified structure ease decision maker from complex analysis that are experienced using other weighting method, such as AHP or ANP [5]. With the combination of both method, FEWA is very powerful in facilitating many imprecise information and thought from expert judgements that come from different backgrounds of function to strengthen the assessment. Since there are so many criteria and hierarchies, multi-hierarchical framework analysis can be used as technology assessment framework because it can identify many criteria and categories based on their hierarchy level. Instead of common single framework, this framework can facilitates multi assessment level.

Based on the assessment result, the position and appropriate strategies for company can be generated using SWOT analysis method. Therefore this research is proposed to combine TAM criteria and multi-hierarchical framework - FEWA and give a recommendation to $\mathrm{PT} X$ as a shipyard company on how to measure and assess the technological capabilities of company.

\section{RESEARCH METHODOLOGY}

This research combines three methods, which are Technology Audit Model (TAM), multi-hierarchical framework - Fuzzy Entropy Weight Approach (FEWA), and SWOT analysis.

\section{A. Technology Audit Model (TAM)}

A technology audit tool called Technology Audit Model (TAM) which includes lot of areas to be considered in technology audit [4]. The purposes of TAM are to determine current technological status, to stress areas of opportunity, and to take advantage of the firm's strong capabilities. TAM is a model consists of three level, with each level going deeper into more specific functions. There are six categories in the upper level, 20 categories in second level, and 46 assessment elements in the third level. Lot of assessment level and component indicates how complete this assessment is for measuring firm's complex processes. TAM scores using fivepoint scale for each assessment elements in third level. 5 is outstanding, 4 is very good, 3 is good, 2 is fair, and 1 is poor [6]. The ideal score is 5 and the avoided score is 1 . (Table 1)

B. Multi-hierarchical framework - Fuzzy Entropy Weight Approach (FEWA)

Fuzzy Entropy Weight Approach (FEWA) is a tool used for evaluating and weighting the criteria.The speciality of this approach is the use of entropy weighting method together with fuzzy number. Fuzzy set theory is designed to deal with the extraction of the primary possible outcome from multiplicity of information that is expressed in vague and imprecise terms [7]. Fuzzy set theory threats vague data as probability distributions in terms of set membership, thus can be used in logical reasoning.

Fuzzy number set shape is varying, the common shape used is triangular fuzzy number. Triangular fuzzy numbers are utilized to consider the vagueness in human thoughts. In triangular fuzzy number, each element $\mathrm{x}$ in $\mathrm{X}$ to a real number in the interval $[0,1]$ is mapped into function $f_{A}(x)$ which represents the grade of membership of $\mathrm{x}$ in A. Then a fuzzy number $\mathrm{A}$ in real line $\mathrm{R}$ is a triangular fuzzy number if its membership function $f_{A}: \mathrm{R} \rightarrow[0,1]$ is:

$$
f_{A}(x)\left\{\begin{array}{l}
\frac{x-c}{a-c}, c \leq x \leq a \\
\frac{x-b}{a-b}, a \leq x \leq b \\
0, \text { otherwise }
\end{array}\right.
$$

The graphical representation of this function can be seen in figure below. With $-\infty<c \leq a \leq b<\infty$, the triangular fuzzy number can be denoted by $(c, a, b)$.

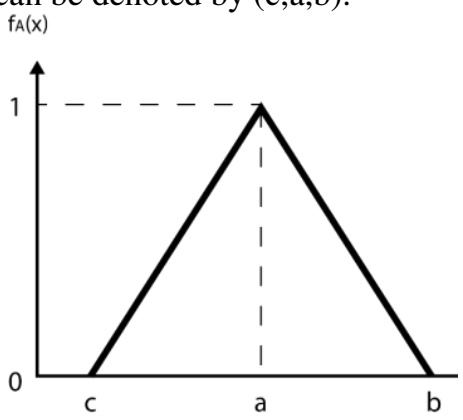

Figure 1. Triangular Fuzzy Number of $(c, a, b)$

While entropy concept was proposed by Shannon \& Weaver in 1949. Since that, this method become well suited approach for measuring the relative contrast intensities of criteria to represent the average intrinsic information transmitted to the decision maker [8]. With score of hesitant fuzzy number, can be calculated the entropy value to obtain the weight of attributes. This combination approach can be called Fuzzy Entropy Weight Approach (FEWA), which is first proposed by Sun Qiaoping and Ouyang Jiewen in a research about energy police selection problem (2015).

FEWA method consist of three important steps which are 
design of decision matrix, determination of entropy values and estimation of criterion weight. The procedures for FEWA are explained as follows[5]:

\section{Step 1: Design of decision matrix.}

Decision matrix is designed using linguistic terms. The fivescale linguistic expressions are employed to evaluate the criteria. They are characterized by triangular fuzzy numbers. (Table 2)

Table 2.

Linguistic Expression and Triangular Fuzzy Numbers

\begin{tabular}{cc} 
Linguistic values & Fuzzy number \\
\hline Poor & $(0,0,0.25)$ \\
Fair & $(0,0.25,0.5)$ \\
Good & $(0.25,0.5,0.75)$ \\
Very Good & $(0.5,0.75,1)$ \\
Outstanding & $(0.75,1,1)$ \\
\hline \hline
\end{tabular}

The triangular fuzzy number above are translated into crisp values using Graded Mean Integration Representation (GMIR) method, used to solving the problem of defuzzification [9]. Let $X_{i j}=\left(c_{i j}, a_{i j}, b_{i j}\right) ; i=1,2, \ldots ., n ; j=1,2, \ldots ., m$; to be the triangular fuzzy number. By the GMIR method, the GMIR $\mathrm{R}\left(\mathrm{X}_{\mathrm{ij}}\right)$ of $\mathrm{X}_{\mathrm{ij}}$ is:

$$
R\left(X_{i j}\right)=\frac{c_{i j}+4 a_{i j}+b_{i j}}{6}
$$

After that, normalization of initial crisp values is conducted. The $R\left(X_{i j}\right)$ value is substracted with the maximum value given for each decision maker [41]. The formula is:

$$
S\left(X_{i j}\right)=R\left(X_{i j}\right)-R\left(X_{i}\right)_{\max }
$$

Then the entropy values for the sub-criteria are determined by first normalising the information a hesitant decision to obtain the normalized score matrix $\hat{s}$ using formula of:

$$
\tilde{s}_{i j}=\frac{s\left(X_{i j}\right)}{\sum_{j}^{m} s\left(X_{i j}\right)} ; \text { where } 0 \leq \tilde{s}_{i j} \leq 1
$$

\section{Step 2: Determination of entropy values}

The normalized values are used to determine the entropy values for the various criteria using calculation of:

$$
E_{j}=-\frac{1}{\ln n} \sum_{i=1}^{n} \tilde{s}_{i j} \ln \tilde{s}_{i j} ; \text { where } 0 \leq E_{j} \leq 1
$$

\section{Step 3: Estimation of criterion weight.}

First the total entropy value can be computed as:

$$
E=\sum_{j=1}^{m} E_{j}
$$

Based on the entropy values for criteria, the weight for each criteria is estimated by:

$$
\begin{gathered}
W_{i j}=\frac{1-E_{i j}}{n-E} \\
\text { where } 0 \leq W_{i j} \leq 1 \text { and } \sum_{j=1}^{n} W_{i j}=1
\end{gathered}
$$

FEWA method fits with multi-hierarchical framework. Basically the purpose of this framework is to generate more options for the company using the advantages of multihierarchical framework.

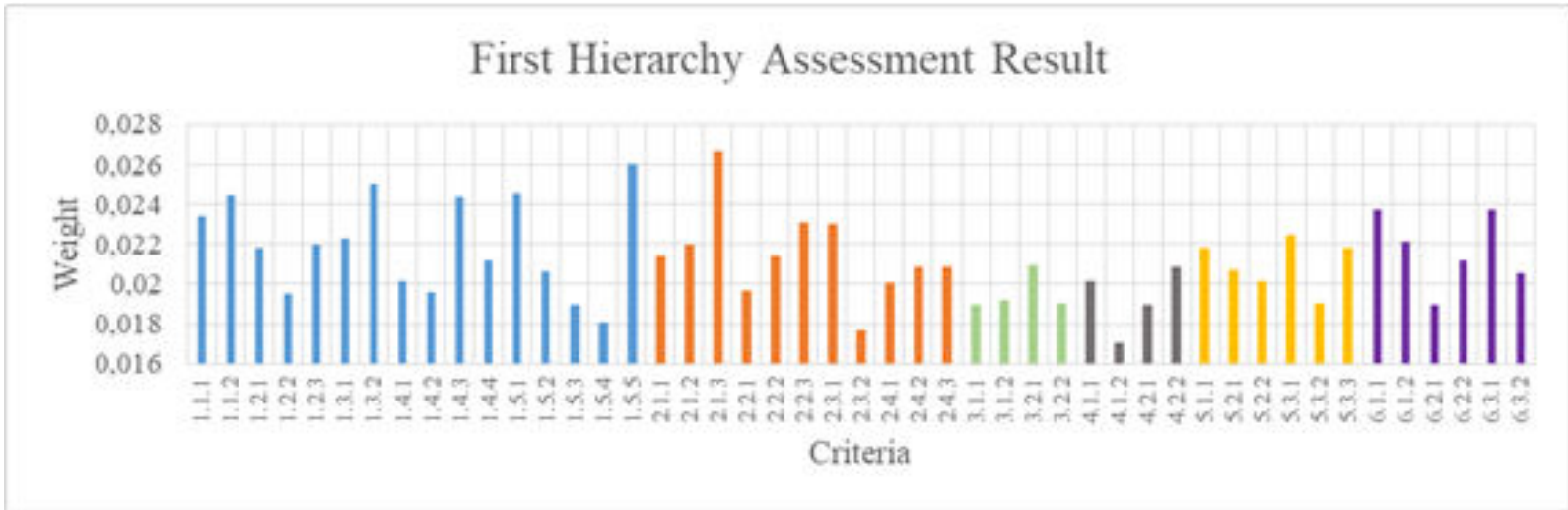

Figure 2. Weight Assessment of First Hierarchy Criteria. 


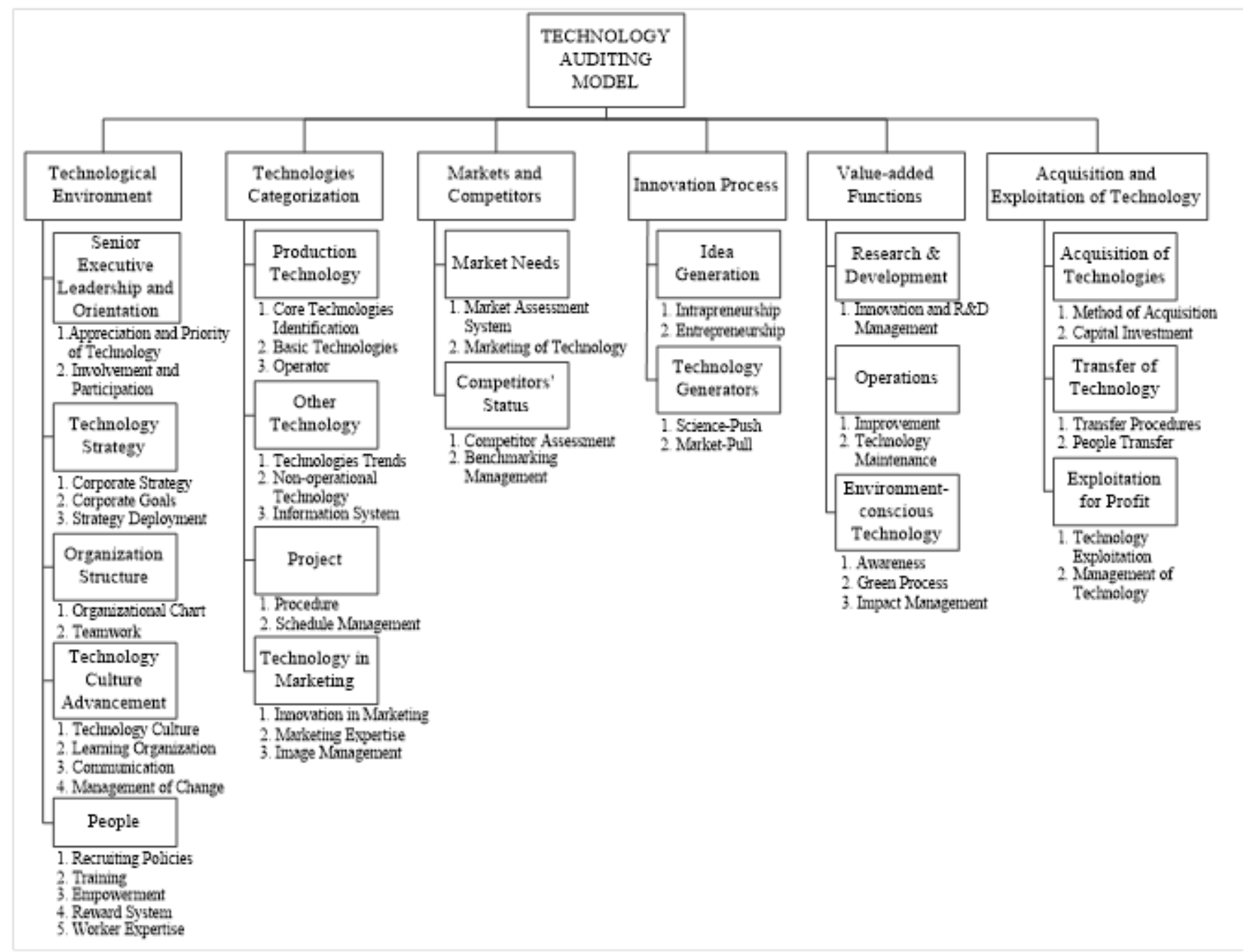

Figure 3. Technology Auditing Model Criteria Framework.

\section{A. SWOT Analysis}

Strengths, weaknesses, opportunities, and threats (SWOT) analysis is a method used by a firm to evaluate their strengths, weaknesses, opportunities, and threats involved in business process. With this framework of SWOT, company can analyze their business process, identify the potential or existing problems then develop improvement strategies. SWOT is a basic model for assesses what a business can and can't do, as well as its potential opportunities and threats. With SWOT method, the obtained information separated into internal factor (strengths and weaknesses) and external factors (opportunities and threats).

\section{RESULT AND ANALYSIS}

After the observation, data collection, and data processing, and the results are obtained as follows.

\section{A. TAM Criteria and Framework Identification}

TAM model is already proved to be match with PT $\mathrm{X}$ business process in general. However, detail adjustment is needed because not all of the sub-component is suitable with this company. The new TAM model has 47 assessment
Table 3.

SWOT Factors

\begin{tabular}{|c|c|c|c|}
\hline \multicolumn{2}{|r|}{ STRENGTH } & \multicolumn{2}{|r|}{ WEAKNESS } \\
\hline S1 & $\begin{array}{l}\text { Good expertise of worker on } \\
\text { ship repair process }\end{array}$ & W1 & $\begin{array}{l}\text { The ship repair process is often } \\
\text { late from schedule }\end{array}$ \\
\hline S2 & $\begin{array}{l}\text { Teamwork culture within } \\
\text { company is high }\end{array}$ & W2 & $\begin{array}{l}\text { Lack of innovation } \\
\text { management for employees }\end{array}$ \\
\hline S3 & Good recruiting policies & W3 & $\begin{array}{l}\text { Bad reward system for } \\
\text { employees }\end{array}$ \\
\hline S4 & $\begin{array}{l}\text { Good information system to } \\
\text { support business process }\end{array}$ & W4 & $\begin{array}{l}\text { Market assessment system is } \\
\text { not good enough }\end{array}$ \\
\hline S5 & $\begin{array}{l}\text { Good SOP of company and its } \\
\text { actualization }\end{array}$ & W5 & $\begin{array}{l}\text { Empowerment management is } \\
\text { not good enough }\end{array}$ \\
\hline S6 & $\begin{array}{l}\text { The company has good } \\
\text { awareness of the environment }\end{array}$ & W6 & $\begin{array}{l}\text { The technology transfer } \\
\text { procedure has not done well }\end{array}$ \\
\hline S7 & $\begin{array}{l}\text { The technology in the } \\
\text { company has been optimally } \\
\text { exploited }\end{array}$ & W7 & $\begin{array}{l}\text { Bad environment management } \\
\text { system in ship repair process }\end{array}$ \\
\hline & OPPORTUNITY & & THREAT \\
\hline $\mathrm{O} 1$ & $\begin{array}{l}\text { Government policies that } \\
\text { support and boost shipyard } \\
\text { industries in Indonesia }\end{array}$ & $\mathrm{T} 1$ & Raw material costs tend to rise \\
\hline $\mathrm{O} 2$ & $\begin{array}{l}\text { The ship regulation for } \\
\text { docking periodically }\end{array}$ & $\mathrm{T} 2$ & $\begin{array}{l}\text { High competition for shipyard } \\
\text { industry }\end{array}$ \\
\hline $\mathrm{O} 3$ & $\begin{array}{l}\text { Growth of inter-island sea } \\
\text { transportation demand }\end{array}$ & $\mathrm{T} 3$ & $\begin{array}{l}\text { Weak domestic industries } \\
\text { supporting the supply of } \\
\text { materials and components }\end{array}$ \\
\hline $\mathrm{O} 4$ & $\begin{array}{l}\text { Cooperation program between } \\
\text { SOEs }\end{array}$ & $\mathrm{T} 4$ & $\begin{array}{l}\text { Different tax incentives for the } \\
\text { shipyard industries outside } \\
\text { Batam }\end{array}$ \\
\hline O5 & $\begin{array}{l}\text { Macroeconomic stability with } \\
\text { relatively good inflation rate }\end{array}$ & $\mathrm{T} 5$ & $\begin{array}{l}\text { Limited access to capital } \\
\text { investment and working capital }\end{array}$ \\
\hline
\end{tabular}


criteria, 19 sub-categories, and 6 main categories.

All of those criteria are grouped into multi-hierarchical framework with 3 level of hierarchy. First level is using all of the 47 criteria as one weighting model. Second level is using all of criteria within each categories to generate weight score. So there will be six different weight score models, according to different categories. Third level of hiearchy framework is using all of criteria within each sub-categories to generate weight score. So there will be 19 different weight score models according to number of sub-categories in the auditing model. The full framework can be seen in Figure 3.

\section{B. Fuzzy Entropy Weight Approach}

FEWA method is used to weight 47 different criteria from proposed technology auditing model to generate technology assessment score. There are 7 experts from different functions within company. The result of first level hierarchy assessment can be seen in Figure 2. From the result, can be seen that the criteria with highest rank is operator criteria (weight of 0.0266 ) included in second category. While the lowest rank is entrepreneurship criteria (weight of 0.017) included in fourth category. While the category with highest rank (biggest average weight) is technological environment category. While the lowest rank is innovation process category. Technologies categorization is the third highest rank although one of its criteria meets the highest rank against all criteria. Assessment for other hierarchy level also conducted to have multipreferences.

\section{SWOT Analysis}

The internal factors of SWOT are obtained from the previous assessment using FEWA method on technology auditing model criteria. While the external factors of SWOT are obtained from the interview and discussion with internal expert of company. The following is the recapitulation table of identified internal factors (strengths and weaknesses) and external factors (opportunities and threats) of PT X. (Table 3)

After that factor evaluation is conducted for both internal and external factors to know the position of company based on SWOT map result. The result of Internal Factor Evaluation (IFE) is 0.986, while the result of External Factor Evaluation (EFE) is 1.381. Therefore, the position of company is located at first quadrant. The strength's score is more dominant than weakness, while the opportunity's score is more dominant than threat. So the appropriate strategy for PT X according to the SWOT method result is aggresive strategy, which is using firm's internal strengths to take advantage of external opportunities.

Therefore based on the identified SWOT matrix strategies, the proposed improvement strategies for PT X are develop knowledge management strategy, develop new production competences of company, develop environment management system within company, develop good schedule management strategy, increase the cooperation with SOEs as value-added for company, and develop good maintenance strategy.

\section{CONCLUSIONS}

The following are the conclusions obtained from this research.

1. The assessment model consists of three hierarchy level with 47 criteria of technology assessment in total. They have already adjusted to fit the company business process.

2. The assessment process is assisted by 7 internal experts of company. FEWA method is used for three different hierarchy level. In first level assessment, criteria with highest rank is operator criteria, while the lowest rank is entrepreneurship criteria. In second level assessment, there are 6 different models according to categories. In third level assessment, there are 19 different models according to sub-categories.

3. In SWOT analysis, the factor identification is conducted using assessment result for internal factor and discussion with company for external factor. From Internal Factor Evaluation (IFE) process, the differences between strength and weakness score is 0.986. From External Factor Evaluation (EFE) process, the differences between opportunity and threat score is 0.533. Using SWOT map, the position of company is located in first quadrant. So the appropriate strategy for company according to SWOT result is aggresive strategy, which is using firm's internal strengths to take advantage of external opportunities.

4. There are six improvement strategies proposed for company. They are develop knowledge management strategy, develop new production competences of company, develop environment management system within company, develop good schedule management strategy, increase the cooperation with SOEs as valueadded for company, and develop good maintenance strategy.

\section{REFERENCES}

[1] www.maritim.go.id, "Bumikan Visi Indonesia Poros Maritim Dunia," 2017. [Online]. Available: https://maritim.go.id/bumikanvisi-indonesia-poros-maritim-dunia-kemenko-kemaritiman-gelarrakornas/ . [Accessed: 29-Sep-2017].

[2] A. Rahman and H. Supomo, "Analisa Kepuasan Pelanggan pada Pekerjaan Reparasi Kapal dengan Metode Quality Function Deployment (QFD)," J. Tek. ITS, vol. 1, no. 1, pp. 297-302, 2012.

[3] T. M. Khalil, Management of Technology: The key to competitiveness and wealth creation. New York: Mc Graw Hill, 2000.

[4] J. Garcia-Arreola, "Technology Effectiveness Audit Model: A Framework for Technology Auditing,” 1996.

[5] D. E. Ighravwe, "A Multi-hierarchical Framework for Ranking Maintenance Sustainability Strategies using PROMETHEE and Fuzzy Entropy Methods,” J. Build. Pathol. Rehabil., 2017.

[6] S. Z. Shirazi, "The Possibility of Industrial Management using Technology Audit Model in the Public Sector Engineering Units of Pakistan,” J. Inf. Commun. Technol., vol. 3, no. 1, pp. 21-28, 2009. L. A. Zadeh, "Fuzzy Sets," Inf. Control, pp. 338-353, 1965.

[8] M. Zeleny, "High Technology Management," Hum. Syst. Manag., pp. 109-120, 1986.

[9] S. H. Chen and C. H. Hsieh, "Representation, ranking, distance, and similarity of L-R type fuzzy number and application," Aust. J. 
Intell. Inf. Process. Syst., vol. 6, no. 4, pp. 217-229, 2000. 